\title{
KARAKTERISTIK CAMPURAN CANGKANG DAN SERABUT BUAH KELAPA SAWIT TERHADAP NILAI KALOR DI PROPINSI BANGKA BELITUNG
}

\author{
Yudi Setiawan \\ Jurusan Teknik Mesin, Universitas Bangka Belitung \\ Jl.Merdeka no. 04 Pangkalpinang \\ E-mail : yudiubb@yahoo.co.id
}

\begin{abstract}
Abstrak
Pada umumnya uap yang diperlukan untuk memutar turbin dan untuk keperluan perebusan pada suatu pabrik kelapa sawit adalah boiler dengan memanfaatkan kembali limbah hasil pengolahannya berupa campuran cangkang dan serabut buah kelapa sawit sebagai bahan bakar. Kualitas suatu bahan bakar tergantung pada nilai kalor, nilai kalor tergantung pada kadar air, kadar abu, kadar volatilematter dan kadar karbon tetap yang terkandung pada bahan bakar. Penelitian ini bertujuan untuk mengetahui pengaruh campuran bahan bakar terhadap nilai kalor. Komposisi pengujian dalam penelitian ini adalah campuran cangkang dan serabut buah kelapa sawit dengan komposisi $80 \%$ serabut $20 \%$ cangkang, $75 \%$ serabut $25 \%$ cangkang, $50 \%$ serabut $50 \%$ cangkang, $25 \%$ serabut $75 \%$ cangkang, $20 \%$ serabut $80 \%$ cangkang. Dari hasil penelitian dapat disimpulkan bahwa komposisi campuran yang memiliki nilai kalor tertinggi adalah campuran $80 \%$ serabut $20 \%$ cangkang dengan nilai kalor $16.584,233 \mathrm{Kj} / \mathrm{Kg}$, kadar air $14,099 \%$, kadar abu 7,776\%, kadar volatillematter $69,872 \%$, karbon tetap 7,478\%. dari penelitian ini juga disimpulkan bahwa semakin tinggi kadar volatilematter dan kadar karbon tetap semakin tinggi nilai kalor yang dihasilkan dan sebaliknya semakin tinggi kadar air dan kadar abu maka nilai kalor yang dihasilkan semakin rendah pada bahan bakar cangkang, serabut buah kelapa sawit.
\end{abstract}

Kata kunci : cangkang, serabut, nilai kalor.

\section{Pendahuluan}

Biomassa meliputi limbah kayu, limbah pertanian, perkebunan, hutan, komponen organik dari industri dan rumah tangga. Kelapa sawit merupakan sumber energi biomassa yang memiliki beberapa kelebihan dibanding dengan energi fosil. Selain sifatnya dapat diperbaharui secara terus menerus, juga lebih ramah terhadap lingkungan. Emisi yang dikeluarkan lebih rendah, terutama gas karbondioksida sehingga mampu mengurangi efek rumah kaca yang menyebabkan pemanasan global. Keunggulan lain membudidayakan dan memanfaatkan biomassa menjadi sumber energi atau biasa disebut dengan energi hijau ini ialah proses pembuatannya yang lebih sederhana dengan nilai investasi yang lebih murah. Penelitian- penelitian terkait penggunaan biomassa sebagai sumber energi telah lama digalakkan dan terus menerus dilaksanakan terutama pada minyak jarak, minyak kelapa sawit, dan minyak goreng bekas pakai. Peneletian ini bertujuan untuk mengatahui karakteristik nilai kalor terhadap variasi campuran serabut dan cangkang kelapa sawit.

D. Muhammad dkk (2008) meneliti kelapa sawit sebagai sumber energi biomassa yang memiliki beberapa kelebihan dibanding dengan energi fosil. Selain sifatnya dapat diperbaharui secara terus menerus, juga lebih ramah terhadap lingkungan. Emisi yang dikeluarkan lebih rendah, terutama gas karbondioksida sehingga mampu mengurangi efek rumah 
kaca yang menyebabkan pemanasan global. Keunggulan lain membudidayakan dan memanfaatkan biomassa menjadi sumber energi atau biasa disebut dengan energi hijau ini ialah proses pembuatannya yang lebih sederhana dengan nilai investasi yang lebih murah. Penelitian- penelitian terkait penggunaan biomassa sebagai sumber energi telah lama digalakkan dan terus menerus dilaksanakan terutama pada minyak jarak, minyak kelapa sawit, dan minyak goreng bekas pakai.

Farel H. Napitupulu (2006) meneliti kelapa sawit diolah dalam suatu pabrik kelapa sawit dengan memanfaatkan kembali limbah hasil pengolahan berupa serabut dan cangkang buah kelapa sawit sebagai bahan bakar.

Wahyu Purwo Raharjo (2007) meneliti pelumas bekas yang digunakan kembali dicampur dengan minyak tanah selanjutnya dipakai sebagai bahan bakar. Dalam penelitiannya nilai kalor bahan bakar semakin meningkat seiring dengan peningkatan kadar campuran.

Darmanto dkk (2006) menganalisa minyak kelapa sebagai bahan bakar alternatif minyak diesel dengan cara mencampurkannya dengan solar dalam komposisi tertentu. Campuran bahan bakar B15 (85 \% solar dan $15 \%$ coconut oil) memiliki keunggulan yakni titik nyalanya yang lebih rendah dan nilai kalor yang lebih besar dibanding campuran bahan bakar lainnya, lebih lanjut disimpulkan bahwa bahan bakar biodiesel minyak kelapa mempunyai potensi besar untuk diaplikasikan sebagai bahan bakar pengganti minyak diesel/solar. Titik nyala dari biodisel kelapa lebih rendah daripada solar sedangkan nilai kalornya setara dengan solar $50 \%$.

Komposisi bahan bakar yang dilakukan pengujian yaitu komposisi 1 adalah bahan bakar campuran $80 \%$ serabut $20 \%$ cangkang, komposisi 2 adalah bahan bakar campuran $75 \%$ serabut $25 \%$ bahan bakar cangkang, komposisi 3 adalah bahan bakar campuran $50 \%$ serabut $50 \%$ cangkang, komposisi 4 adalah bahan bakar campuran $25 \%$ serabut $75 \%$ cangkang, komposisi 5 adalah bahan bakar campuran $20 \%$ serabut $80 \%$ cangkang buah kelapa sawit dengan massa pengujian 1 gram dalam setiap pengujian per komposisi.

Pengambilan komposisi di pabrik kelapa sawit PT. Sinar Mas di Profinsi Kep. Bangka Belitumh dimana komposisi merupakan limbah pengolahan buah kelapa sawit menjadi coconut palm oil. Serabut dan cangkang buah kelapa sawit yang akan diuji dilakukan penumbukan kemudian dilakukan pengayakan sehingga menjadi partikelpartikel kecil dalam bentuk serbuk (70-80 mesh) untuk mendapatkan nilai maksimal campuran serabut dan cangkang buah kelapa sawit. Lalu dilakukan nilai kalor dan pengujian proksimat untuk menghasilkan fraksi massa dari kadar air (moisture content), kadar abu (ash), zat yang mudah menguap (volatille matter) dan kadar karbon tetap (fixed carbon).

\section{Metodologi}

Komposisi campuran yang dilakukan pengujian yaitu komposisi 1 adalah bahan bakar campuran $80 \%$ serabut $20 \%$ cangkang, komposisi 2 adalah bahan bakar campuran $75 \%$ serabut $25 \%$ bahan bakar cangkang, komposisi 3 adalah bahan bakar campuran $50 \%$ serabut $50 \%$ cangkang, komposisi 4 adalah bahan bakar campuran $25 \%$ serabut $75 \%$ cangkang, komposisi 5 adalah bahan bakar campuran $20 \%$ serabut $80 \%$ cangkang, $100 \%$ cangkang dan $100 \%$ serabut buah kelapa sawit dengan massa pengujian 1 gram dalam setiap pengujian per komposisi dengan ukuran 325 mesh. Setelah itu dilakukan pengujian nilai kalor dan proksimat yang menghasilkan fraksi massa dari kadar air (moisture content), kadar abu (ash), zat yang mudah menguap (volatille 
matter) dan kadar karbon tetap (fixed carbon).

\section{Hasil Dan Pembahasan}

\section{Kadar Abu}

Abu merupakan kotoran yang tidak akan terbakar. abu menyebabkan dalam pembakaran akan mengurangi kapasitas pembakaran, menyebabkan penggumpalan dan penyumbatan didalam ruang bakar.

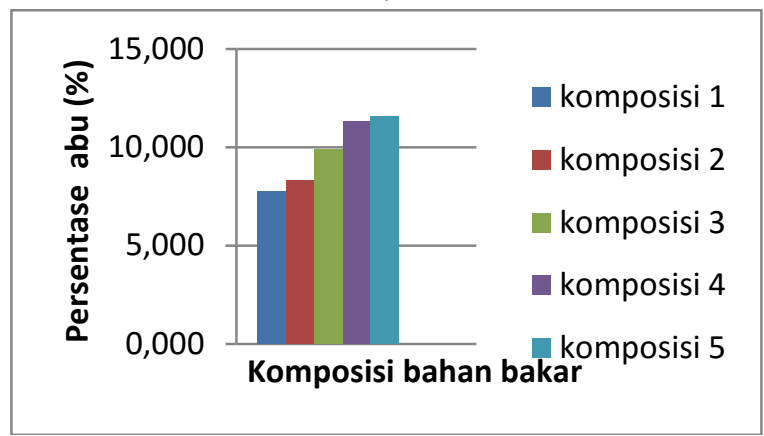

Gambar 1. Kadar abu dalam bahan bakar

Dari gambar 1. nilai kadar abu terendah adalah komposisi 1 dengan nilai 7,776 \%, komposisi 2 dengan nilai 8,329\%, komposisi 3 dengan nilai 9,876\%, komposisi 4 dengan nilai $11,282 \%$ dan komposisi 5 dengan nilai $11,566 \%$. Campuran yang memiliki kadar abu tertinggi adalah komposisi 5 dengan nilai 11,566\% . Efrata Pratenta Meliala dan Iwan Setyadi (2010). Kadar abu berpengaruh negatif terhadap nilai kalor, semakin tinggi kadar abu semakin rendah nilai kalornya. Hal ini kemungkinan disebabkan oleh sifat fisis dan kotoran yang melekat pada saat proses penimbunan bahan bakar dan tempat penimbunannya ditempat terbuka, sesuai dengan penelitian bahwa abu yang terkandung didalam bahan bakar padat merupakan mineral yang tidak dapat terbakar yang tertinggal selama proses pembakaran oleh karena itu abu dapat menurunkan mutu bahan bakar karena menurunkan nilai kalor.

\section{Kadar Air}

Daniel Romatua (2007) menyatakan air yang terkandung dalam bahan bakar menyebabkan penurunan mutu bahan bakar karena dapat menurunkan nilai kalor dan memerlukan sejumlah kalor untuk penguapan menurunkan titik nyala, memperlambat proses pembakaran dan menambah volume gas buang.

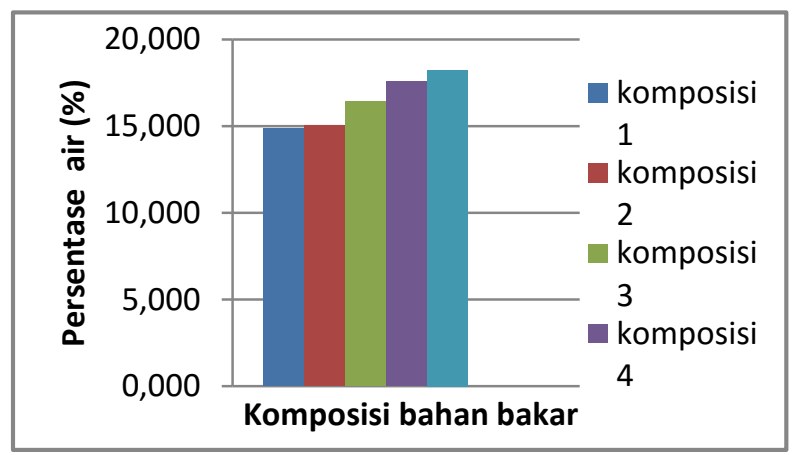

Gambar 2. Kadar air dalam bahan bakar

Gambar 2 dapat dilihat nilai kadar air terendah komposisi 1 dengan nilai $14,875 \%$, komposisi 2 dengan nilai $15,037 \%$, komposisi 3 dengan nilai $16,427 \%$, komposisi 4 dengan nilai $17,579 \%$, komposisi 5 cangkang dengan nilai $18,247 \%$. Kadar air berpengaruh negatif terhadap nilai kalor dengan semakin tinggi kadar air dalam bahan bakar cangkang, serabut dan campurannya maka semakin rendah nilai kalornya.

Dalam penelitian ini nilai kadar air tertinggi adalah nilai kadar air tertinggi campuran bahan bakar serabut dan cangkang adalah komposisi 5 dengan nilai 18,247\%, nilai kadar air terendah pada komposisi 1 dengan nilai kadar air 14,875\%. Banyaknya nilai kadar air yang terkandung dalam bahan bakar serabut, cangkang dan campuran serabut dan cangkang kemungkinannya disebabkan oleh kelembaban suhu suatu 
daerah yang berbeda dan tempat penimbunannya sehingga setelah proses penimbunan bahan bakar terjadi penambahan kadar air baik oleh alam maupun dari pengembunan bahan bakar itu sendiri sebelum limbah serabut, cangkang dan campurannya digunakan kembali sebagai bahan bakar.

\section{Kadar Volatile matter}

Daniel Romatua (2007) Tingginya kadar volatile matter pada suatu bahan bakar akan berbanding lurus dengan peningkatan nyala api, panjangnya nyala api dalam bahan bakar akan mempengaruhi kestabilan panas yang dipancarkan bahan bakar pada proses pembakaran. Semakin banyak kadar volatile matter pada bahan bakar maka semakin mudah bahan bakar terbakar dan menyala.

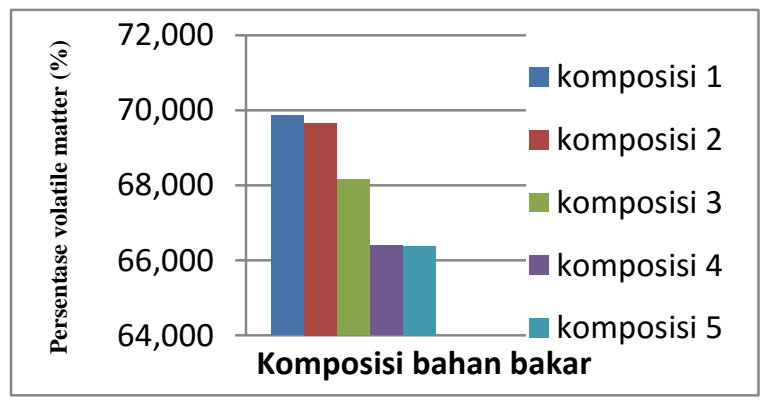

Gambar 3 Kadar volatile matter dalam bahan bakar

Dari gambar 3 nilai volatile matter tertinggi adalah pada komposisi 1 dengan nilai $69,872 \%$, komposisi 2 dengan nilai $69,655 \%$, komposisi 3 dengan nilai $68,157 \%$, komposisi 4 dengan nilai $66,400 \%$ dan komposisi 5 dengan nilai $66,385 \%$. Kadar volatile matter berpengaruh positif terhadap nilai kalor dimana semakin tinggi nilai volatile matter semakin cepat proses pembakaran awal bahan bakar sehingga panas yang dikeluarkan semakin tinggi dan pembakaran karbon tetap semakin cepat terbakar
Dalam penelitian ini kadar volatile matter tertinggi adalah spesifikasi campurannya komposisi 1 dengan nilai $69,872 \%$ dan terendah pada spesifikasi komposisi 5 dengan nilai $66,385 \%$. Kemungkinan tingginya nilai kadar volatile matter dikarenakan rendahnya densitas serabut dibandingkan cangkang sedangkan rendahnya nilai kadar volatile matter disebabkan oleh tingginya densitas cangkang buah kelapa sawit. Dari analisa diatas semakin banyaknya kadar volatile matter pada pencampuran bahan bakar cangkang dan serabut maka kadar karbon akan semakin rendah hal ini kemungkinannya disebabkan pada kadar volatile matter masih terdapat kadar karbon yang menguap pada saat pembakaran berlangsung.

\section{Kadar Karbon Tetap}

Kadar karbon tetap seperti gambar dibawah ini.

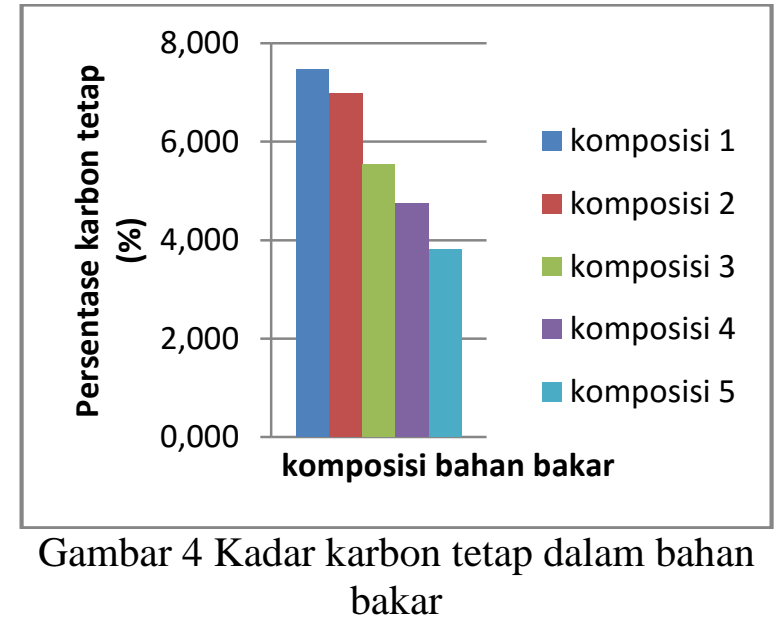

Dari gambar 4 nilai karbon tetap tertinggi adalah pada komposisi 1 dengan nilai $7,478 \%$, komposisi 2 dengan nilai 6,980\%, komposisi 3 dengan nilai 5,541\%, komposisi 4 dengan nilai 4,379\%, komposisi 5 dengan nilai 3,802\%. Dalam penelitian ini kadar karbon tetap tertinggi adalah komposisi 1 dengan nilai $7,478 \%$ dan terendah pada komposisi 5 dengan nilai 
$3,802 \%$, hal ini disebabkan pada komposisi 1 tingginya nilai volatile matter sehingga karbon lebih cepat terbakar dan kalor pembakaran terdistribusi dengan baik. Karbon tetap pada bahan bakar sangat mempengaruhi nilai kalor bahan bakar dimana semakin tinggi karbon tetap akan semakin tinggi nilai kalor bahan bakar hal ini sesuai dengan penelitian Daniel Romatua; 2007 bahwa karbon tetap menunjukkan sebagai pembangkit utama panas proses pembakaran dan perkiraan kasar terhadap nilai panas bahan bakar. Semakin besar nilai karbon dalam pembakaran maka akan memperlambat kecepatan pembakaran.

\section{Analisa Nilai Kalor}

Nilai kalor menunjukkan kalor yang berpindah bila hasil pembakaran sempurna. Nilai kalor ditentukan dengan menggunakan standar uji bom Kalorimeter menurut srandar ASTM D- 2015.

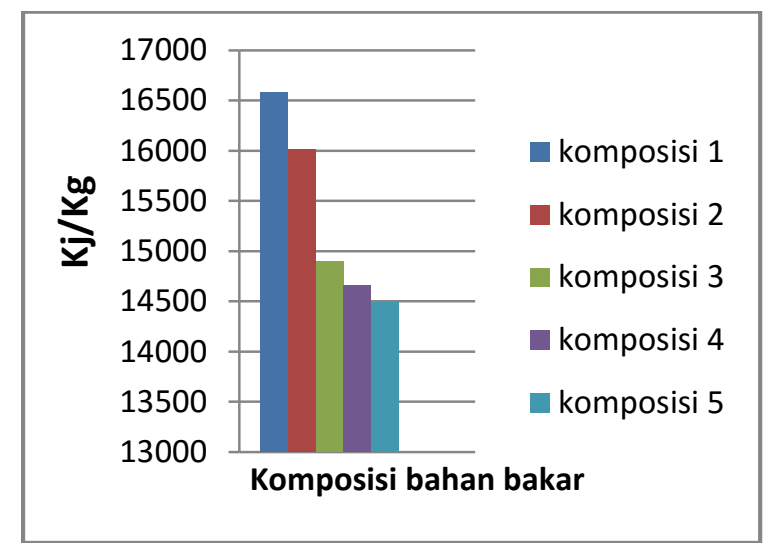

Gambar 5 Diagram Nilai Kalor bahan bakar

Dari gambar 5 diatas menunjukkan perbandingan nilai kalor dari 5 spesimen yang dilakukan pengujian bahwa hasil nilai kalor tertinggi yaitu komposisi campuran $80 \%$ serabut $20 \%$ cangkang $16.115,391$ $\mathrm{Kj} / \mathrm{Kg}$, campuran $75 \%$ serabut $25 \%$ cangkang 16.011,981 Kj/Kg, campuran, $50 \%$ serabut $50 \%$ cangkang $14.898,862$ $\mathrm{Kj} / \mathrm{Kg}$, campuran $25 \%$ serabut $75 \%$ cangkang $14.654,286 \mathrm{Kj} / \mathrm{Kg}$ dan terendah pada campuran $20 \%$ serabut $80 \%$ cangkang dengan nilai $14.490,825 \mathrm{Kj} / \mathrm{Kg}$. Dari hasil pengujian penelitian ini nilai kalor tertinggi adalah komposisi campuran $80 \%$ serabut $20 \%$ cangkang sebesar $16.115,391 \mathrm{Kj} / \mathrm{Kg}$.

Tabel 1 Hasil pengujian

\begin{tabular}{|c|c|c|c|c|c|}
\hline $\begin{array}{c}\text { Samp } \\
\text { el }\end{array}$ & $\begin{array}{c}\text { Kompos } \\
\text { isi } 1 \\
\text { Kal/g } \\
\end{array}$ & $\begin{array}{l}\text { Kompos } \\
\text { isi } 2 \\
(\mathrm{Kal} / \mathrm{g}) \\
\end{array}$ & $\begin{array}{c}\text { Kompos } \\
\text { isi } 3 \\
(\mathrm{Kal} / \mathrm{g}) \\
\end{array}$ & $\begin{array}{c}\text { Kompos } \\
\text { isi } 4 \\
(\mathrm{Kal} / \mathrm{g}) \\
\end{array}$ & $\begin{array}{c}\text { Kompos } \\
\text { isi } 5 \\
\text { (Kal/g) } \\
\end{array}$ \\
\hline & 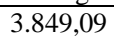 & $3.824,39$ & $3.558,5$ & $3.500,1$ & $3.461,07$ \\
\hline kalor & 5 & & 0 & 6 & \\
\hline
\end{tabular}

Analisa kalor suatu bahan bakar dimaksudkan untuk memperoleh data tentang energi kalor yang dapat dibebaskan oleh suatu bahan bakar dengan terjadinya reaksi/proses pembakaran. Eddy dan Budi (1990) nilai kalor menunjukkan kalor yang berpindah bila hasil pembakaran sempurna. Nilai kalor yang tinggi dalam bahan bakar dipengaruhi oleh kandungan volatile matter yang tinggi sehingga mudah terbakar dan tingginya kadar karbon tetap akan menghasilkan waktu bahan bakar terbakar lebih lama.

Selain kadar volatile matter dan kadar karbon tetap yang tinggi nilai kalor akan meningkat dengan semakin rendahnya nilai kadar abu dan kadar air bahan bakar cangkang dan serabut buah kelapa sawit. Grafik perbandingan seperti pada gambar dibawah ini:

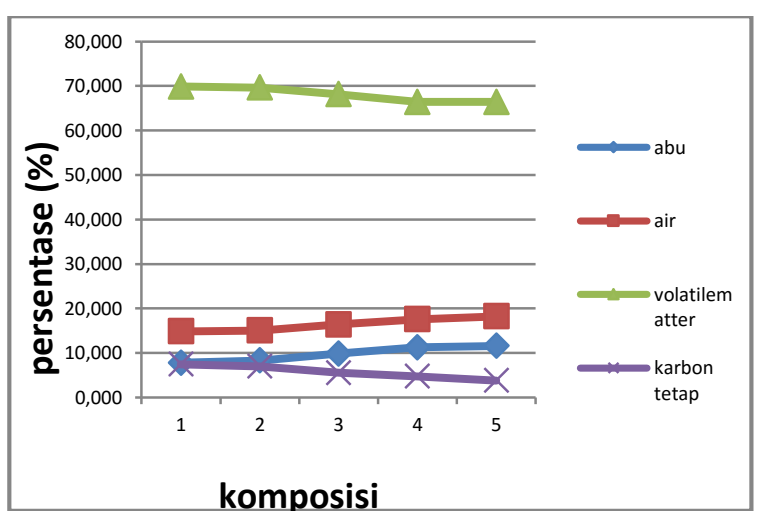

Gambar 6 Grafik perbandingan bahan bakar cangkang dan serabut buah kelapa sawit 
Grafik diatas diketahui bahwa nilai kalor bahan bakar tertinggi dipengaruhi oleh nilai kadar abu, kadar air, kadar volatile matter dan kadar karbon tetap dimana dengan semakin nilai kadar karbon dan kadar volatile matter akan meningkatkan nilai kalor pembakaran, semakin rendah nilai kadar abu dan kadar air dalam sebuah bahan bakar akan meningkatkan nilai kalor pembakaran. Nilai kalor pembakaran pada bahan bakar serabut, cangkang dan campuran serabut, cangkang buah kelapa sawit, nilai kalor yang paling tinggi pada komposisi bahan bakar campuran $80 \%$ serabut dan $20 \%$ cangkang kelapa sawit dengan nilai kalor $16.584,233 \mathrm{Kj} / \mathrm{Kg}$.

\section{Kesimpulan}

Kadar air dan abu berpengaruh negatif terhadap nilai kalor dimana semakin rendah kadar air maka penyalaan awal dari campuran bahan bakar cangkang dan serabut semakin baik dimana semakin tinggi kadar air maka penyalaan semakin sulit dan kalor yang dihasilkan semakin kecil dan semakin tinggi kadar abu maka semakin kecil nilai kalor yang dihasilkan, sedangkan kadar volatile matter dan karbon tetap berpengaruh positif terhadap nilai kalor dengan semakin tinggi nilai volatile matter semakin cepat proses pembakaran awal bahan bakar sehingga panas yang dikeluarkan semakin tinggi dan pembakaran karbon tetap semakin cepat terbakar, semakin tinggi kadar karbon tetap maka besar nilai kalor yang dihasilkan. Nilai kalor tertinggi adalah pada campuran serabut $80 \%$ cangkang $20 \%$ serabut buah kelapa sawit sebesar $16.115,391 \mathrm{Kj} / \mathrm{Kg}$.

\section{Daftar Pustaka}

[I] Darmanto, Seno., Ireng Sigit A. 2006. Analisa Biodisel Minyak Kelapa Sebagai Bahan Bakar Alternatif Minyak Diesel. Semarang : Traksi. Vol. 4. No. 2, Desember 2006.

[II] Daniel Romatua., 2007. Kajian Ekperimental Pengaruh Pengurangan Kadar Air Terhadap Nilai Kalor Terhadap Bahan Bakar Padat.Teknik Mesin Universitas Sumatera Utara.

[III] Djazuli Muhammad. dan Bambang Prastowo. 2008. Bahan Bakar Nabati Alternatif Pengganti Minyak Tanah. Warta Penelitian dan Pengembangan Pertanian. Vol.30. No. 24. 2008.

[IV] Eddy dan Budi., 1990, Teknik Pembakaran Dasar dan Bahan Bakar, Jurusan Teknik Mesin, Fakultas Teknologi Industri -ITS, Surabaya.

[V] E.P. Meliala, dan Iwan S. 2010. Analsisis Pemilihan Bahan Bakar untuk Pengoperasian Continous Annealing Furnace (CAF). Jakarta: BPPT.

[VI] Farel H. Napitupulu. 2006. Analisis Nilai Kalor Bahan Bakar Serabut dan Cangkang Sebagai Bahan Bakar Ketel Uap di Pabrik Kelapa Sawit. Medan: Universitas Sumatera Utara.

[VII] Wahyu Purwo Raharjo. 2007. Pemanfaatan Oli Bekas Dengan Pencampuran Minyak Tanah Sebagai Bahan Bakar Pada Atoming Burner. Teknik Mesin Universitas Sebelas Maret Surakarta 